\title{
Aborto eqüino por Leptospira sp.
}

\author{
Leptospira sp. as a cause of equine abortion
}

\section{Caroline Argenta Pescador ${ }^{1}$ Luís Gustavo Corbellini ${ }^{1}$ Alexandre Paulino Loretti ${ }^{2}$ Elsio Wunder Júnior ${ }^{3}$ Fernanda Junges Frantz ${ }^{3}$ David Driemeier $^{4}$}

\section{- RELATO DE CASO -}

\section{RESUMO}

\begin{abstract}
Descreve-se um caso de aborto eqüino por Leptospira sp. em um feto de 6 meses proveniente de um estabelecimento localizado próximo a Porto Alegre/RS. As lesões macroscópicas se caracterizaram por icterícia e hemorragias distribuídas difusamente sobre a pele, mucosa oral, tecido subcutâneo, pulmão, coração e sistema gastrintestinal. O fígado estava aumentado de tamanho, friável e de coloração amarelada. Os rins apresentavam hemorragias petequiais na superfície capsular e na superfície de corte observaram-se palidez da região cortical e medular. Cortes de rim e sistema nervoso central, corados por WarthinStarry, revelaram a presença de espiroquetas nos túbulos, glomérulos e substância branca do encéfalo. Cultivo aeróbio de amostras de fígado e pulmão não revelaram crescimento bacteriano significativo. O teste de imunofluorescência direta para Leptospira sp. foi positivo e a sorologia fetal resultou numa titulação de 80 para o sorovar copenhageni e 40 para os sorovares icterohaemorragiae e pomona.
\end{abstract}

Palavras-chave: aborto, eqüino, Leptospira sp.

\section{ABSTRACT}

This report describes an abortion on 6-monthold equine aborted fetus that has been caused by Leptospira $s p$. Main lesions included jaundice and hemorrhages diffusely scattered throughout the skin, oral mucosa, subcutaneous tissues, lungs, heart and gastrointestinal system. The liver was enlarged, pliable and yellow colored. The cortical and medullar of the kidneys were pale and petechial hemorrhages were present on the capsular surface. Warthin-Starry stained slices of the kidneys and central nervous system revealed the presence of spirochaetes within the tubules, glomeruli and white matter of the encephalo. Aerobic cultivation from samples of the liver and lungs were negative. The direct immunofluorescence test for Leptospira sp. was positive and the fetus's serological test resulted titers of 80 against sorotype copenhageni and 40 against the sorotypes icterohaemorragiae and pomona.

Key words: abortion, equine, Leptospira sp.

\section{INTRODUÇÃO}

A Leptospirose é uma zoonose bacteriana prevalente em todo o mundo. É causada por espiroquetas da espécie Leptospira interrogans, que apresentam mais de 212 sorovares, agrupados em 23 sorogrupos (ELLIS, 1994). Este agente pode afetar animais domésticos, selvagens e humanos, representando, portanto, um importante problema de saúde pública (BARWICK et al., 1997). A transmissão da leptospirose depende de condições favoráveis para a sobrevivência do organismo no meio ambiente, do número de animais portadores em uma população e do tempo de duração que os animais portadores abrigam as leptospiras (HUNTER \& HERR, 1994). A umidade, temperatura e o pH são pontos críticos para a sobrevivência do agente no meio ambiente (RIETCORREA \& LEMOS, 2001). A infecção ocorre diretamente através da pele e mucosas que entram em contato com urina, fluidos placentários, leite ou água e alimentos contaminados, podendo também ser transmitida pelo sêmen e por via transplacentária

\footnotetext{
${ }^{1}$ Médico veterinário aluno do Programa de Pós-graduação em Ciências Veterinárias, Universidade Federal do Rio Grande do SUl (UFRGS). ${ }^{2}$ Médico Veterinário, Professor Assistente, Departamento de Patologia Clínica Veterinária, Faculdade de Medicina Veterinária, UFRGS.

${ }^{3}$ Aluno de Graduação em Medicina Veterinária Faculdade de Veterinária UFRGS

${ }^{4}$ Medico Veterinário, Professor Adjunto, Departamento de Patologia Clínica Veterinária, Faculdade de Medicina Veterinária, UFRGS, CP 15094, Av. Bento Gonçalves, 9090, 91540-000, Porto Alegre, RS. E-mail: davetpat@vortex.ufrgs.br Autor para correspondência.
} 
(BOLIN \& PRESCOTT, 1999). Na espécie eqüina, os sorovares de Leptospira spp. mais freqüentemente encontrados são pomona, icterohaemorrhagiae, canicola, grippotyphosa, hardjo, australis, pyrogenes, tarassovi, butembo, ballum e autumnalis (SWART et al., 1982).

A infecção por Leptospira sp. em eqüinos é principalmente subclínica, sendo considerada como uma causa importante de abortos (usualmente ao 6o mês de gestação), nascimento de animais fracos ou prematuros, natimortos e mortalidade neonatal. Febre, icterícia, problemas oculares e morte por nefrite intersticial têm também sido observadas (HONG et al., 1993; HUNTER \& HERR, 1994). A presença de leptospiras no interior do globo ocular causa uveíte progressiva, envolvendo úvea posterior, córnea, retina e nervo óptico, podendo inclusive, resultar em cegueira (HUNTER \& HERR, 1994). A avaliação macroscópica em fetos eqüinos abortados é normalmente prejudicada pela autólise (HUNTER \& HERR, 1994). Entretanto, quando presentes, são caracterizadas por icterícia, hemorragias sob a forma de petéquias e equimoses no pulmão, mucosa traqueal, coração e mucosa gastrintestinal. Os rins apresentam-se com uma coloração amarelada e o fígado friável e com coloração amarelo-alaranjada (HODGIN et al., 1989). Microscopicamente, há dissociação hepatocelular, infiltração inflamatória linfocitária nas tríades portais, placentite caracterizada por trombose, vasculite e infiltração de células inflamatórias no estroma juntamente com hiperplasia adenomatosa cística e necrose do epitélio. Nefrite, pneumonia, encefalite e miocardite são também descritas (POONACHA et al. 1994).

O diagnóstico definitivo de leptospirose em fetos abortados através do isolamento é limitado devido às dificuldades do cultivo (ELLIS \& MICHINA, 1976). Os testes de imunofluorescência direta e sorologia fetal têm sido usados com resultados satisfatórios no diagnóstico de leptospirose em tecidos e no soro de fetos abortados, respectivamente (DONAHUE et al., 1991). A detecção de Leptospira spp. no sêmen eqüino foi recentemente descrita no Brasil (SCARCELLI et al., 2001). Levantamentos sorológicos realizados por autores nacionais (GIORGI et al., 1981) relatam que os eqüinos apresentam anticorpos para diferentes sorovares de leptospiras, tendo sido o isolamento da icterohaemorrhagiae o primeiro conseguido no Brasil a partir de um feto eqüino abortado (GIORGI et al., 1981). Este trabalho descreve um caso de aborto eqüino por leptospirose ocorrido no município de Porto Alegre.

\section{RELATO DO CASO}

Em junho de 2002, um feto eqüino abortado de 6 meses de idade, da raça quarto de milha, foi encaminhado ao Setor de Patologia Veterinária da Universidade Federal do Rio Grande do Sul. Durante a realização da necropsia, fragmentos de diversos órgãos foram coletados e fixados em formalina tamponada $10 \%$, sendo processados através de métodos convencionais para exames histológicos rotineiros e corados por hematoxilina-eosina e coloração de prata (WarthinStarry). Foram realizadas impressões de secções de rim para o teste de imunofluorescência direta, utilizando-se anticorpo comercial multivalente na diluição de 1:20 (MILLER et al., 1989). Foi realizado cultivo bacteriano aeróbio de fragmentos de fígado e pulmão. Amostras de soro fetal também foram coletadas para a realização do teste de microaglutinação, partindo de uma diluição de 1:10, para os seguintes sorovares: australis, autumnalis, bratislava, canicola, copenhageni, kirshneri, grippotyphosa, hardjobovis, hebdomadis, icterohaemorrhagiae, pomona, pyrogenes, wolffi.

\section{RESULTADOS}

Conforme informações obtidas com a proprietária, a égua que abortou havia sido vacinada contra tétano, gripe e encefalomielite, mas não para leptospirose. A propriedade possui um total de 20 eqüinos da raça quarto de milha, de diferentes idades. Casos esporádicos de aborto estavam ocorrendo na propriedade.

Durante a necropsia, observou-se icterícia e hemorragias (petéquias, equimoses e sufusões) distribuídas, difusamente, sobre a pele, mucosa oral e tecido subcutâneo (Figura 1). O fígado estava aumentado de tamanho, friável e de coloração amarelada. Tanto a serosa quanto a mucosa do intestino apresentavam-se intensamente avermelhadas. Havia hemorragias puntiformes na serosa do ceco. A cortical e a medular renais estavam pálidas e hemorragias petequiais estavam presentes na superfície capsular. No estômago, foram encontradas petéquias e sufusões na serosa, além de conteúdo sanguinolento no seu interior. Esplenomegalia, hidrotórax, hemorragias petequiais e equimóticas na superfície epicárdica, bem como edema pulmonar e sufusões na pleura visceral também foram constatadas (Figura 2). Microscopicamente, havia dissociação difusa de hepatócitos, hepatite linfoplasmocitária e pericolangite mononuclear difusas subagudas discretas, nefrite intersticial 


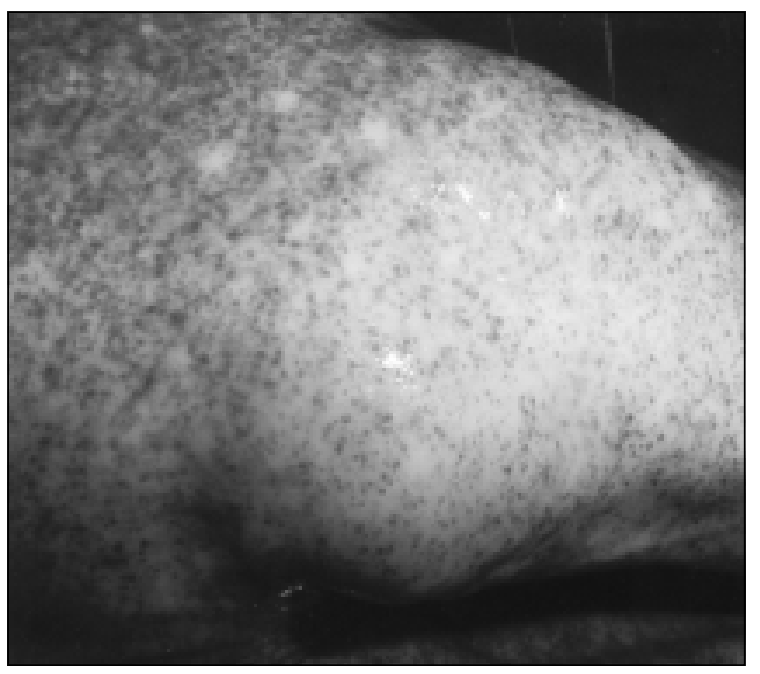

Figura 1 - Feto eqüino abortado. Membro anterior apresentando múltiplas hemorragias petequiais na pele.

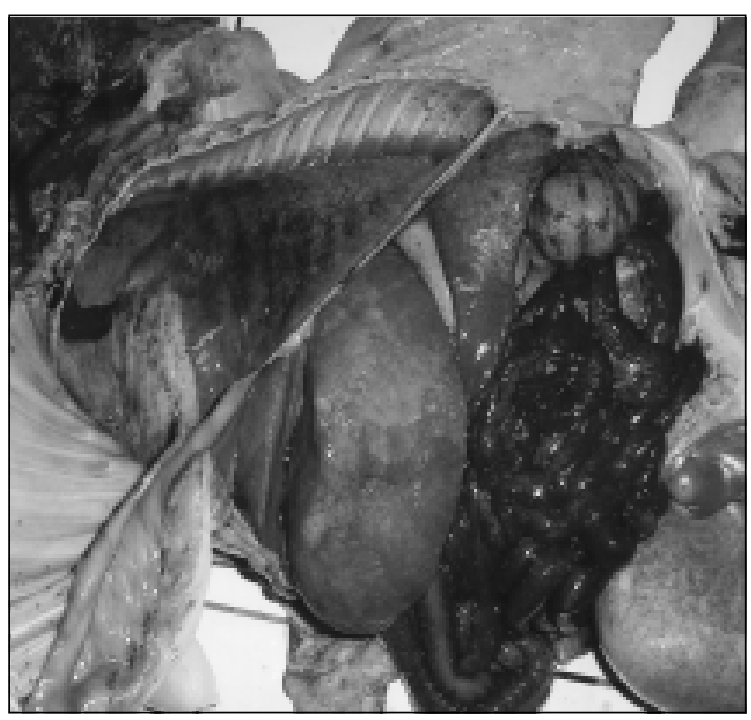

Figura 2 - Feto eqüino abortado demonstrando icterícia generalizada da carcaça, fígado de coloração amarelada, intestino difusamente avermelhado e a presença de líquido na cavidade torácica.

linfoplasmocitária difusa subaguda discreta, hemorragia peribronquiolar difusa severa e hipoplasia folicular difusa no baço. No cérebro, constatou-se hemorragia multifocal moderada com presença de neutrófilos no interior de alguns focos de hemorragia. Os cortes de rim, fígado e cérebro corados por WarthinStarry revelaram a presença de espiroquetas de coloração enegrecida no interior dos túbulos e glomérulos renais, sinusóides hepáticos e substância branca do sistema nervoso central. O cultivo bacteriano de amostras de fígado e pulmão não revelou crescimento bacteriano significativo. Leptospira sp., fortemente marcadas com fluoresceína foram observadas no exame de imunofluorescência direta em impressões de rim (Figura 3). Em algumas áreas, observaram-se até 10 espiroquetas por campo. A sorologia fetal revelou uma titulação de 80 para o sorovar copenhageni e 40 para os sorovares icterohaemorragiae e pomona. Foram coletadas amostras de fígado, rim, líquido da cavidade torácica e conteúdo estomacal para tentativa de isolamento do agente. Tais amostras foram inoculadas em meio EMJH semi-sólido com 5-fluorouracil, mas os resultados foram inconclusivos em função da contaminação.

\section{DISCUSSÃO}

A leptospirose tem sido considerada como causa de abortos e mortes neonatais em eqüinos (DONAHUE et al., 1991). Em diversos países, os eqüinos têm apresentado sorologia bastante variável, não demonstrando a ocorrência de um sorovar preferencial (HUNTER \& HERR, 1994). Laboratórios de diagnóstico relatam dificuldades no isolamento da Leptospira, tanto pela fragilidade da natureza do agente, como pelos custos e a complexidade do isolamento, além do prolongado período de incubação

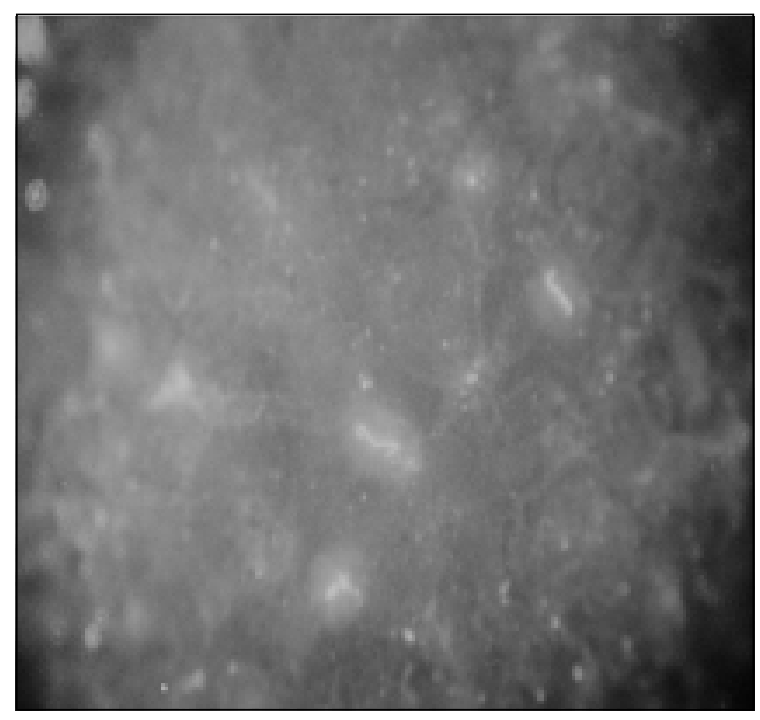

Figura 3 - Impressão de rim do feto eqüino abortado. Imunofluorescência direta com anticorpo comercial multivalente na diluição de 1:20. Presença de espiroquetas marcadas com fluoresceína. 1000X

Ciência Rural, v. 34, n. 1, jan-fev, 2004. 
necessário (DONAHUE et al., 1991). Tais aspectos justificam, em parte, porque a enfermidade ainda não é totalmente conhecida (BOLIN \& PRESCOTT, 1999). Tecidos de animais que morreram dentro de um período de 24 horas e que são refrigerados, bem como tecidos que são submetidos ao congelamento não são adequados para o isolamento da leptospira (DONAHUE et al., 1991). A técnica de imunofluorescência direta utilizada neste caso, confirmou a suspeita de leptospirose, demonstrando ser um teste bastante útil no diagnóstico definitivo desta doença. As amostras cultivadas em meio EMJH foram inviáveis para confirmação através do isolamento em função do alto grau de contaminação (ELLIS \& MICHINA, 1976).

Os resultados sorológicos encontrados auxiliaram na determinação dos sorogrupos e respectiva titulação de anticorpos envolvidos na infecção, complementando o diagnóstico. Fetos eqüinos são considerados imunocompetentes (DONAHUE et al., 1991), sendo que a titulação de anticorpos encontrada no soro fetal, neste caso, representa uma resposta imune à infecção. A alta titulação observada sugere uma infecção recente, uma vez que a diluição inicial no exame de microaglutinação em fetos abortados é de 1:10 (BOLIN \& PRESCOTT, 1999). Ao contrário da freqüente condição de autólise observada em fetos abortados, o que muitas vezes é responsável pela rotineira ausência de achados macroscópicos e microscópicos (HUNTER \& HERR, 1994; RADOSTITS et al., 1994 RIET-CORREA \& LEMOS, 2001), o feto examinado no presente estudo apresentava-se em bom estado de conservação, demonstrando, de maneira muito evidente, as lesões descritas. O presente diagnóstico baseou-se nos achados de necropsia, na histopatologia, imunofluorescência direta e no perfil sorológico. Os resultados encontrados comprovam a infecção por Leptospira sp. no feto eqüino abortado, devendo-se, portanto, considerar a possibilidade da ocorrência desta enfermidade como causa de problemas reprodutivos também na espécie eqüina.

\section{REFERÊNCIAS BIBLIOGRÁFICAS}

BARWICK R.S. et al. Risk factors associated with the likelihood of leptospiral seropositivity in horses in the state of New York. Am J Vet Res, v.58, p.1097-1103, 1997.

BOLIN C.A.; PRESCOTT J.F. Leptospirosis. In:
HOWARD J.L.; SMITH R.A. Current veterinary therapy. 4.ed. Philadelphia: Saunders, 1999. V.1, p.352357 .

DONAHUE J. M. et al. Diagnosis and prevalence of leptospira infection in aborted and stillborn horses. J Vet Diagn Invest, v.3, p.148-151, 1991.

ELLIS, W.A.; MICHINA, S.W. Bovine leptospirosis: Demonstration of leptospires of the Hebdomadis serogroup in aborted fetuses and a premature calf. Vet Rec, v.27, p.430432, 1976.

ELLIS, W.A. Leptospirosis as a cause of reproductive failure. In: MILleR, R.B. The Veterinary Clinics of North America: Food Animal Pratice, Philadelphia, v.10, p.463476, 1994.

GIORGI, W. et al. Leptospirose em eqüinos: inquérito sorológico e isolamento de Leptospira icterohaemorrhagiae de feto abortado. Instituto Biológico São Paulo, v.47, p.47-53, 1981

HODGIN, E. et al. Leptospira abortion in horses. J Vet Diagn Invest, v.1, p.283-287, 1989.

HONG C.B. et al. Equine abortion and stillbirth in central Kentucky during 1988 and 1989 following seasons. J Vet Diagn Invest, v.5, p.560-566, 1993.

HUNTER, P.; HERR, S. Leptospirosis. In: COETZER, J.A.W.; THOMSON, G.R.; TUSTIN, R.C. Infectious diseases of Livestock. Oxford : Oxford University, 1994. V.2, p.9971008, 1994.

MILlER, D. A.; WILSON, M.A.; KIRKBRIDE, C. A. Evaluation of multivalent Leptospira fluorescent antibody conjugates for general diagnostic use. J Vet Diagn Invest, v.1, p. 146-149, 1989.

POONACHA K. B. et al. The role of Leptospira Interrogans serovar Pomona type Kennewicki as a cause of abortion and stillbirth in mares. In: INTERNATIONAL Conference, 1994, Tokyo, Japan. Proceedings... Tokyo: Equine Infections disease, 1994. VII. p.113119 .

RADOSTITS O.M.; BLOOD D.C.; GAY C.C. Veterinary medicine. 7.ed. London : Baillière Tindall, 1994. p. 1763 .

RIET-CORREA, F.; LEMOS, R.A.A. Leptospirose. In: RIETCORREA, F. et al. Doenças de ruminantes e eqüinos. 2.ed. São Paulo : Varela, 2001. V.1, p.275-284.

SCARCELLI, E. et al. Detecção de Leptospira spp. em sêmen eqüino pela técnica da Reação da Polimerase em Cadeia (PCR). Arquivos do Instituto Biológico São Paulo, v.68, p.102, 2001

SWART, K. S.; CALVERT, K.; MENEY, C. The prevalence of antibodies to serovars of Leptospira interrogans in horses. Aust Vet J, v.59, p.25-27, 1982. 